\title{
162. 小児の重心動摇と頭部動摇におよぼす視運動刺激の影響
}

\author{
坂口正範・田口喜一郎・宮下善和（信大）
}

視連動刺激が重心動摇と頭部動摇にいかなる影暗を およぼすかについて，成人を対象として検討した報告 はいくつかみられるが，小児例についてはほとんど検 討されていない。

今回われわ机は小児の身体平衡機能の特徵を明らか にするために，7〜9歳の小学生20名と20２6歲の成 人20名について，無刺激時および視運動刺激時（水平 方向, 垂直方向，30/sec，60/sec，90/sec）のそれぞれ 60秒間の重心動摇と頭部動摇を測定し, 次の結果を得 た. 1）小学生群, 成人群とも視運動刺激時の重心動摇 および頭部動摇軌跡距離は無刺激時に比べて有意に大 きい値を示す場合が多かった。2）小学生群では視運動 刺激時の重心動摇おうよ゙頭部動摇面積は無刺激時に比 べて有意に大きい值を示す一方, 成人群では視運動刺 激時と無刺激時の間に有意差を認女なかった。3）小 学生の重心動摇星の Y 軸・X 軸成分比は成人群に比心゙ て有意に大きい值を示した。一方頭部動摇量の $\mathrm{Y}$ 軸・
X軸成分比は小学生群と成人群の間に有意差を諗め ない場合が多かった４）重心動摇平均周波数はX 軸 成分に拈いては小学生群と成人群との間に有意差は認 められなかったが，Y軸成分では小学生群が成人群に 比べて有意に大きい場合が多かった。一方頭部動採平 均周波数は $\mathrm{X}$ 軸成分, $\mathrm{Y}$ 軸成分とも小学生群は成人群 に比べて有意に大きい值を示した.5）小学生群では重 心動摇軌跡距離に対する頭部動摇軌跡距離の比は成人 群よりも有意に大きかった。以上から小見は成人に比 心゙て重心動摇，頭部動摇とも視運動刺激の影響をより 强く受けること, 重心の前後動㩊が大きいこと, 重心 動摇に対する頭部動採の比率が大きいことが示唆され た. 質問 高橋正紿(慶大). 視運動刺激中の感賞 (回転感) と動摇の大きさの間に関係が見られたか。 応答 自覚的なめまい感についての検討は行っていな い.

\section{3．視標追跡時の重心動摇と頭部動摇の関係}

一正常高齢者について—

後藤昭信・菊川正人・田中映子・田口喜一郎（信大）

健康な高齢者の視標追跡刺激下の重心動摇ならびに 頭部動摇の特徵について調べた。

対象 被験者は60歳以上の平衡障害, 眼疾患のない 健康な高龄者 24 名とした。

方法 被験者如頭部動摇計（第一医科製）を頭に装 着し, 重心動摇計（三栄IG06）の上でロンベルグ姿勢 をとってもらった．使用した頭部動摇計は直流ポテン シオメータにより頭部の変位をX軸とY軸に分けて記 録でき，同時に頭部の回転も記録できる。刺激装置は TV 画面を使し, 視標を眼前 $40 \mathrm{~cm}$ に設定し, 視野角度 が水平30度になるように視標の振幅を調節した。刺激 条件としてに開眼時一点固視の他，此弦波 $0.1,0.25$, $0.5,0.75,1.0,1.5 \mathrm{~Hz}$ の速度を変えた 6 刺激を用い た. 重心動摇, 頭部動摇, 頭部回転を on line でテクニ カルコンピュータ（TEAC 社 PS-9816) に入力し，重 心動摇, 頭部動摇各々軌跡距離, 動摇面積, $\mathrm{Y}$ 軸・ $\mathrm{X}$ 軸 成分比, 0 から $1 \mathrm{~Hz}$ までの平均周波数を求め, さらに 喠跡距離ならびに動摇面積の頭部動摇と重心動摇の比 を算出した。

結果 1) 軌跡距離：重心動摇では一点固視に比バ
視標追跡時の方が有意に増加した。ピークは平均值て は 0.5 から $0.75 \mathrm{~Hz}$ に認めた。対照群と比較すると 個々の值は大きいがピークは同じであった。しかし 個々の変動を見るとピークが遅い視標速度にあった りト゚ークかはっきりしない場合など対照群よりも一 定のパターンを示さなかった。頭部動摇も重心動摇と 同様の結果であった，2） $\mathrm{Y}$ 軸・X 軸成分比：重心動摇 では一点固視に比べ視標追跡時の方が有意に減少し た。軌跡距離の増加は相对的に左右方向の重心動摇量 が增加するためと考えられた，対照群の值と比較する と大きくなり,左右方向の動摇量の増加の率は小さく, 頭部動摇の值に近づいた。頭部動摇では対照群と一点 固視, 視標追跡時共に同じ変動を示した.3）高龄者で は遅い指標刺激時において頭部回転を認めることがあ つた。

まとめ高路者では視標追跡刺激の負荷を加えると 対照群と同様に重心動摇，頭部動摇共に動摇量が増之 た。相対的には前後方向よりは左右方向の動摇㻎が增 加したが，頭部動摇に比べると重心動摇の左右方向の 動摇量の増加は少ないのが特徵と思われた。 